medRxiv preprint doi: https://doi.org/10.1101/2021.05.13.21257179; this version posted May 17, 2021. The copyright holder for this preprint (which was not certified by peer review) is the author/funder, who has granted medRxiv a license to display the preprint in perpetuity.

It is made available under a CC-BY-NC-ND 4.0 International license .

\title{
Sensitive period-regulating genetic pathways and exposure to adversity shape risk for depression
}

\author{
Yiwen $\mathrm{Zhu}^{1,2}$ \\ Min-Jung Wang ${ }^{1,2}$ \\ Katherine M. Crawford ${ }^{1}$ \\ Juan Carlos Ramírez-Tapia ${ }^{1}$ \\ Alexandre A. Lussier ${ }^{1,3}$ \\ Kathryn A. Davis ${ }^{1}$ \\ Christiaan de Leeuw ${ }^{4}$ \\ Anne E. Takesian ${ }^{5}$
}

Major Depressive Disorder Working Group of the Psychiatric Genomics Consortium ${ }^{\#}$

Takao K. Hensch, $\mathrm{PhD}^{6,7}$

Jordan W. Smoller, MD, ScD ${ }^{1,2,3,8}$

Erin C. Dunn ${ }^{1,3,8,9}$

1 Center for Genomic Medicine, Massachusetts General Hospital, Boston, MA

2 Department of Epidemiology, Harvard T.H. Chan School of Public Health

3 Department of Psychiatry, Harvard Medical School, Boston, MA

4 Department of Complex Trait Genetics, Center for Neurogenomics and Cognitive Research, Amsterdam Neuroscience, Vrije Universiteit Amsterdam, Amsterdam, Netherlands

5 Eaton-Peabody Laboratories, Massachusetts Eye \& Ear and Department of

Otorhinolaryngology and Head/Neck Surgery, Harvard Medical School, Boston, MA, USA

6 Department of Molecular and Cellular Biology, Center for Brain Science, Harvard University, Cambridge, MA

7 Department of Neurology, F.M. Kirby Neurobiology Center, Boston Children's Hospital, Harvard Medical School, Boston, MA

8 Stanley Center for Psychiatric Research, The Broad Institute of Harvard and MIT, Cambridge, MA

9 Harvard Center on the Developing Child, Cambridge, MA

\# Authorship list appears in the Supplemental Materials

Correspondence: Address correspondence to:

Yiwen Zhu, MS, Department of Epidemiology, Harvard T.H. Chan School of Public Health, 677 Huntington Avenue, Boston, MA 02115; email: yiwenzhu[@]mail[.]harvard[.]edu.

Erin C. Dunn, ScD, MPH, Psychiatric and Neurodevelopmental Genetics Unit, Center for Genomic Medicine, Massachusetts General Hospital, 185 Cambridge Street, Simches Research Building 6th Floor, Boston, MA 02114; email: edunn2[@]mgh[.]harvard[.]edu. Phone: 617-7269387; Fax: 617-726-0830; Website: www.thedunnlab.com

Keywords: genetic association study; depression; depressive symptoms; sensitive periods; ALSPAC 
medRxiv preprint doi: https://doi.org/10.1101/2021.05.13.21257179; this version posted May 17, 2021. The copyright holder for this preprint (which was not certified by peer review) is the author/funder, who has granted medRxiv a license to display the preprint in perpetuity.

It is made available under a CC-BY-NC-ND 4.0 International license .

Abstract

Animal and human studies have documented the existence of developmental windows (or sensitive periods) when experience can have lasting effects in shaping brain structure or function,

49 behavior, and disease risk. Sensitive periods for depression likely arise through a complex

50 interplay of genes and experience, though this possibility has not been explored. We examined

51 the effect of sensitive period-regulating genetic pathways identified in preclinical animal studies,

52 alone and in interaction with socioeconomic disadvantage, a common childhood adversity, on

53 depression risk. Using a translational approach, we: (1) performed gene-set association analyses

54 using summary data from a genome-wide association study of depression $(n=807,553)$ to assess

55 the effects of three gene sets (60 genes) shown in animal studies to regulate sensitive periods; (2)

56 evaluated the developmental expression patterns of these sensitive period-regulating genes using

57 data from BrainSpan ( $\mathrm{n}=31)$, a transcriptional atlas of postmortem brain samples; and (3) tested

58 gene-by-development interplay by analyzing the combined effect of common variants in

59 sensitive period genes and timing of exposure to socioeconomic disadvantage within a

60 population-based birth cohort $(\mathrm{n}=6254)$. The gene set regulating sensitive period opening

61 associated with increased depression risk. Notably, six of the 15 genes in this set showed

62 developmentally regulated gene-level expression. A genome-wide polygenic risk score-by-

63 environment analysis showed socioeconomic disadvantage during ages 1-5 years were

64 independently associated with depression risk, but no gene-by-development interactions were

65 found. Genes involved in regulating sensitive periods may be implicated in depression

66 vulnerability and differentially expressed across the life course, though larger studies are needed

67 to identify developmental interplays. 
medRxiv preprint doi: https://doi.org/10.1101/2021.05.13.21257179; this version posted May 17, 2021. The copyright holder for this preprint (which was not certified by peer review) is the author/funder, who has granted medRxiv a license to display the preprint in perpetuity.

It is made available under a CC-BY-NC-ND 4.0 International license .

\section{Introduction}

Sensitive periods are stages of heightened plasticity when experience can have

particularly strong and enduring effects on brain structure, behavior, and health [1-5]. To date

71 sensitive periods have been most commonly studied with respect to sensory systems and related

72 domains, including vision, hearing, and language learning, in animals [6-8] and humans [9,10].

73 This research has revealed that sensitive period plasticity occurs through an orchestration of

74 genes and life experiences [11,12]. As shown in Figure 1 and previously summarized elsewhere

75 [12], robust evidence from in vivo experiments with genetically modified mice or rats has shown

76 that several dozen genes regulate the opening, closing, and expression of sensitive periods in the

77 visual and auditory systems [12-15]. For instance, opening genes (e.g., Bdnf or Gad2 [12,16,17])

78 initiate, accelerate, or delay the onset of sensitive periods by regulating parvalbumin (PV) cell

79 maturation and altering the ratio of excitatory and inhibitory circuit activity. Closing genes (e.g.,

80 Acan, Rtn4r) regulate the formation of perineuronal nets (PNNs), which operate as a "molecular

81 brake" of sensitive period plasticity [18]. Expression genes (e.g., Nr2a or Stat1 [19,20]) maintain

82 the duration of sensitive periods by circuit rewiring and consolidation. Beyond the primary

83 sensory cortex, these genetic pathways have been recently implicated in plasticity mechanisms

84 that configure the prefrontal cortical network [21], which regulates cognition and mood

$85[8,18,21]$. Thus, alterations in the genetic structure of sensitive period regulation have

86 developmental impacts across brain regions and could give rise to varying levels of psychiatric

87 vulnerability.

88 To that end, accumulating evidence from molecular studies suggest genetic dysregulation

89 of sensitive period plasticity may explain risk for neuropsychiatric disorders. For instance, in

90 mouse models of autism, researchers observed mistimed sensitive period onset due to premature 
medRxiv preprint doi: https://doi.org/10.1101/2021.05.13.21257179; this version posted May 17, 2021. The copyright holder for this preprint (which was not certified by peer review) is the author/funder, who has granted medRxiv a license to display the preprint in perpetuity.

It is made available under a CC-BY-NC-ND 4.0 International license .

91 or impoverished PV circuits [24, 25]. In both clinical patients and animal models, reduction of

92 sensitive period triggers (PV+ interneurons) or molecular brakes (PNNs) and sensitive period-

93 related transcriptional or epigenetic aberrations were shown to confer greater risk for

94 schizophrenia [24-26]. Recent findings from large-scale genome-wide association studies

95 (GWAS) also point towards associations between variants located in some of the genes

96 implicated in sensitive period regulation (e.g., GABBR1 [22-25], GRIN2A [26-30], NCAM1

97 [23,31], NCAN [30]) and neuropsychiatric illnesses, such as schizophrenia, depression, and

98 bipolar disorder.

99 Environmental perturbations during sensitive periods are also associated with risk for

100 neuropsychiatric disorders [32,33]. Observational epidemiologic studies in humans show that

101 exposure to childhood adversity may have time-dependent effects on brain structure and function

102 [34], as well as social, emotional, and behavioral processes, ranging from fear conditioning to

103 stress reactivity and psychopathology symptoms $[4,35,36]$. This work has generally found that

104 adversity during the first five years of life is associated with the greatest risk for psychiatric

105 outcomes relative to exposure after age five or no exposure [4]. Adversity is thought to disrupt

106 sensitive period functioning through experience-expectant processes, wherein during restricted

107 periods of development, the brain is primed through genetic instruction to expect a normative set

108 of environmental inputs [37]. Experiences of childhood adversity, including acts of social

109 commission (e.g., physical or sexual abuse) or social and material omission (e.g., neglect,

110 poverty) [38], are therefore understood as violations of expected environmental inputs that can

111 lead to impaired brain plasticity and mental disorders [39].

112 Depression is a disorder classically viewed as governed by the interplay between genetic

113 variations and time-dependent experiences over the life course [40,41]. While the timing and 
medRxiv preprint doi: https://doi.org/10.1101/2021.05.13.21257179; this version posted May 17, 2021. The copyright holder for this preprint (which was not certified by peer review) is the author/funder, who has granted medRxiv a license to display the preprint in perpetuity.

It is made available under a CC-BY-NC-ND 4.0 International license .

114 duration of depression-related sensitive periods are unknown, preclinical and molecular studies

115 have implicated sensitive period biology in etiologic pathways of depression risk. For example,

116 the molecular signature of sensitive period closure, PNNs, has protective effects against

117 oxidative stress [42]. Oxidative stress responses have been connected to the pathophysiology of

118 major depressive disorder $[43,44]$ and appear impacted by childhood adversity $[45,46]$.

119 Moreover, deficits in GABAergic transmission, which plays a key role in regulating sensitive

120 period timing, can alter susceptibility to early life stress [47]. Therefore, stress exposures during

121 developmental periods of heightened vulnerability may give rise to more severe symptoms of

122 depression, especially among individuals with genetic variations linked to disrupted sensitive

123 period timing [47-49].

$124 \quad$ However, to our knowledge, no studies to date have investigated the independent and

125 joint roles of gene sets regulating developmental plasticity and exposure to time-varying early

126 life adversity on depression risk. In this study, we pursued the overarching hypothesis that

127 genetic variation governing sensitive period plasticity interacts with adverse life experiences

128 during specific developmental windows to shape risk for depression. We tested this hypothesis

129 using a translational approach, bridging and triangulating sources of evidence (from animal

130 models and human studies) [50], types of data (cross-sectional and longitudinal), and disciplines

131 (genetics, developmental neuroscience, and epidemiology). Adopting a pathway-based approach

132 similar to previous studies on neuropsychiatric disorder etiology [51,52], we focused on three

133 sets of genes encompassing existing molecular evidence for sensitive period biology, which

134 regulate the opening ( $\mathrm{n}=15$ genes), closing $(\mathrm{n}=39$ genes), and expression $(\mathrm{n}=8$ genes) of sensitive

135 periods (Figure 1). The following three research questions are sequentially investigated (Figure

136 2): 
medRxiv preprint doi: https://doi.org/10.1101/2021.05.13.21257179; this version posted May 17, 2021. The copyright holder for this preprint (which was not certified by peer review) is the author/funder, who has granted medRxiv a license to display the preprint in perpetuity.

It is made available under a CC-BY-NC-ND 4.0 International license . meta-analysis of depression, which included 414,055 cases and 892,299 controls from three

154 large-scale depression samples: UK Biobank, the Psychiatric Genomics Consortium (PGC), and 155 23andMe, Inc. [53]. Across subsamples, depression was defined using minimal (e.g., self156 reported symptoms) and deep phenotyping (e.g., structured clinical interviews) approaches.

157 Therefore, the analyses captured genetic architecture of general depression, instead of strict 158 clinical diagnosis of major depressive disorder. Details about the genotyping and quality control 159 procedure are provided by Howard et al. [53]. 
medRxiv preprint doi: https://doi.org/10.1101/2021.05.13.21257179; this version posted May 17, 2021. The copyright holder for this preprint (which was not certified by peer review) is the author/funder, who has granted medRxiv a license to display the preprint in perpetuity.

It is made available under a CC-BY-NC-ND 4.0 International license . each gene [54]. For the gene-set level analyses, we grouped the 60 sensitive period genes into

172 their respective sets based on their biological functioning (Figure 1). To perform a competitive 173 gene-set analysis, we compared the gene-level results for our three sensitive period gene sets to

174 the gene-level results of the rest of the genome; this test determines whether the average

175 association between genes in the given set and the trait of interest were stronger than that of

176 other genes not in the set. We included a corrected p-value that empirically accounts for multiple

177 testing, using 10,000 random permutations. This gene-set approach, rather than a single genetic

178 variant-level analysis, was chosen to test specific biological pathways and understand their

179 potential for identifying therapeutic targets [54]. Moreover, based on the observation of

180 polygenicity (i.e., many thousands of loci each conferring very small risk), aggregating

181 functionally-consistent signals could substantially improve statistical power [40,55]. 
medRxiv preprint doi: https://doi.org/10.1101/2021.05.13.21257179; this version posted May 17, 2021. The copyright holder for this preprint (which was not certified by peer review) is the author/funder, who has granted medRxiv a license to display the preprint in perpetuity.

It is made available under a CC-BY-NC-ND 4.0 International license .

Of note, five genes in our analysis were located in the Major Histocompatibility Complex

183 (MHC), a region of the genome involved in human immunity that contains polymorphic loci

184 with long-range linkage-disequilibrium (LD) patterns [56]. Although these features could make

185 interpretation of SNP-level associations more difficult, we did not remove SNPs in the extended

186 MHC region, as LD is explicitly modeled in MAGMA to produce unbiased results (see

\section{Supplemental Materials).}

Research Question 2: Investigating the developmental regulation of depression-implicated

190 sensitive period gene sets

191 Gene expression data

192 We investigated the temporal expression patterns of sensitive period genes within the left

193 hemisphere of three brain regions involved in the pathophysiology of depression (amygdala,

194 hippocampus, and medial prefrontal cortex (mPFC)) [57]. Data came from BrainSpan [58,59]

195 (http://www.brainspan.org), a transcriptional atlas of healthy, post-mortem brain donors (ages

1965.7 weeks post-conception to 82 years) without large-scale genomic or other abnormalities (see

197 Supplemental Materials). In brief, the 31 postnatal donors studied represented both sexes (42\%

198 were female) and were predominantly of European ancestry (58\%). BrainSpan investigators

199 classified donors by developmental stage at time of death: (1) 0-5 months (n=3); (2) 6-11 months

$200 \quad(n=3) ;(3) 1-5$ years $(n=2) ;(4) 6-11$ years $(n=3) ;(5) 12-19$ years $(n=4) ;(6) 20-39$ years $(n=9) ;(7)$

$20140-59$ years $(n=4)$; and (8) 60+ $(n=3)$. Prenatal donors and right hemisphere data were not

202 analyzed here, due to issues with data suitability or availability (see Supplemental Materials).

203 Quality-controlled, quantile normalized exon microarray data [60] were downloaded

204 from Gene Expression Omnibus (GEO; GSE25219). For each brain region, expression levels for 
medRxiv preprint doi: https://doi.org/10.1101/2021.05.13.21257179; this version posted May 17, 2021. The copyright holder for this preprint (which was not certified by peer review) is the author/funder, who has granted medRxiv a license to display the preprint in perpetuity.

It is made available under a CC-BY-NC-ND 4.0 International license .

205 all probes within an exon were averaged to obtain an expression value for each exon. Probes

206 were annotated to genes using the UCSC Human Genome (hg19) reference sequence. Similar to

207 prior studies [61,62], we used the median of all exons within each gene as the estimate of gene

208 expression. Expression values are presented in $\log (2)$ values; thus, each one-unit difference

209 represents a doubling of expression. Although RNA-sequencing data were available in

210 BrainSpan, that dataset contained only one-third of the sample size, which would have been too

211 small for our analysis (see Supplemental Materials).

212 Data Analysis

213 To investigate whether sensitive period gene expression patterns were developmentally

214 regulated, we tested the hypothesis that developmental stage at time of death explained a

215 significant amount of variation in gene expression. Specifically, we performed multiple

216 regression analysis using an omnibus F-test to compare the full model (with developmental stage

217 included as a categorical variable) to a baseline model (only adjusting for two principal

218 components capturing genetic ancestry). The amount of variation in gene expression additionally

219 explained by developmental stage was quantified using the increase in $\mathrm{R}^{2}$. To reduce multiple

220 testing burden, we focused only on genes in the gene sets associated with depression risk from

221 analyses of the first research question.

222 Further, to explore whether certain genetic variants could shape developmental

223 expression patterns of sensitive period genes implicated in depression, we tested the interactions

224 between genotype and developmental stage on expression. Genotype was included as a

225 categorical variable instead of the conventional additive model, to capture the potential nonlinear

226 relationship between genotype and trajectories of gene expression; developmental stage was

227 modeled as an ordinal variable, with both linear and quadratic effects to account for nonlinearity 
medRxiv preprint doi: https://doi.org/10.1101/2021.05.13.21257179; this version posted May 17, 2021. The copyright holder for this preprint (which was not certified by peer review) is the author/funder, who has granted medRxiv a license to display the preprint in perpetuity.

It is made available under a CC-BY-NC-ND 4.0 International license .

228 while retaining model parsimony. An F-test was then performed to compare the genotype-by-

229 timing model (with the interaction terms) to the baseline model (without the interaction terms).

230 Of note, we restricted these exploratory analyses to the mPFC, as we saw the most evidence for

231 developmental regulation in this brain region. More details are provided in the Supplemental

232 Materials.

$234 \quad$ Research Question 3: Investigating interactions between genome-wide and gene set-level genetic

235 liability to depression, timing of exposure to adversity, and depressive symptoms in development

236 (i.e., developmental gene-environment interplay)

\section{Dataset and measures}

238 To examine potential developmental gene-environment interplay (dGxE), we analyzed

239 data from 6254 child participants in the Avon Longitudinal Study of Parents and Children

240 (ALSPAC), a UK-based prospective, longitudinal birth-cohort of children followed for more

241 than two decades [63-65]. Ethical approval for the study was obtained from the ALSPAC Ethics

242 and Law Committee and the Local Research Ethics Committees. Consent for biological samples

243 has been collected in accordance with the Human Tissue Act 2004 [66]. More details are

244 available on the ALSPAC website, including a fully searchable data dictionary:

245 http://www.bristol.ac.uk/alspac/researchers/our- data/.

246 The analytic sample included all participants who were genotyped and had data on the

247 outcome, which was average depressive symptoms across adolescence, spanning ages 10.5 years

248 to 23 years $[67,68]$. Details about the genotype data collection and quality control procedure are

249 provided in Supplemental Materials. Depressive symptoms across adolescence were measured

250 by averaging clinically administered and child self-reports of depressive symptoms using the 
medRxiv preprint doi: https://doi.org/10.1101/2021.05.13.21257179; this version posted May 17, 2021. The copyright holder for this preprint (which was not certified by peer review) is the author/funder, who has granted medRxiv a license to display the preprint in perpetuity.

It is made available under a CC-BY-NC-ND 4.0 International license .

251 Short Mood and Feelings Questionnaire (SMFQ) [69] (Supplemental Materials). We focused

252 on average symptoms to maximize the analytic sample size and measure general levels of

253 symptoms across development.

254 We studied socioeconomic disadvantage as our measure of adversity, because it is one of

255 the most commonly-occurring and frequently studied adversity types [70,71], and has been

256 consistently associated with psychopathology symptoms in childhood [72] and adulthood [73,74].

257 Prior literature [72,75] and our own analyses (see Supplemental Materials) provided

258 converging evidence of a time-dependent relationship between exposure to socioeconomic

259 disadvantage and depressive symptoms. In ALSPAC, socioeconomic disadvantage was

260 measured as a time-varying construct based on maternal reports of the extent to which the family

261 had difficulty affording items for the child, rent or mortgage, heating, clothing, or food. Based on

262 prior evidence and preliminary findings, exposure was defined as a three-level variable: no

263 exposure before age 7, exposure during the identified sensitive period (i.e., ages 1-5), and

264 exposure at other time points outside the sensitive period.

265 Data Analysis

266 Using summary statistics provided by Howard et al. as weights [53], we generated a

267 polygenic risk score (PRS) representing risk for depression conferred by common variants in the

268 gene set(s) associated with depression in the analyses for the first research question, which was

269 comprised of 3617 SNPs before clumping. As a comparison, we additionally generated a

270 genome-wide PRS including all SNPs associated with depression in the summary statistics at the

271 threshold of $p<0.05$. Prior to computing the PRS, clumping was performed to eliminate SNPs

272 that were in high LD (based on an $r^{2}$ threshold of 0.25). PRS calculations were conducted in

273 PLINK 1.90 [76]. 
medRxiv preprint doi: https://doi.org/10.1101/2021.05.13.21257179; this version posted May 17, 2021. The copyright holder for this preprint (which was not certified by peer review) is the author/funder, who has granted medRxiv a license to display the preprint in perpetuity.

It is made available under a CC-BY-NC-ND 4.0 International license .

All analyses controlled for the following covariates (measured at childbirth): sex,

275 maternal age, number of previous pregnancies, home ownership, highest level of maternal

276 education, and maternal marital status. We also adjusted for the top four principal components to

277 control for potential population stratification. To reduce potential bias and maximize statistical

278 power, missing exposure and covariate data were multiply imputed using the MICE package [77]

279 in R among participants with complete outcome data. All subsequent multiple regression

280 analyses were performed using 20 imputed datasets and the estimates were combined to account

281 for variations between- and within- imputed datasets.

\section{Results}

284 1) Are genetic pathways involved in regulating sensitive periods associated with depression

$285 \quad \underline{\text { risk? }}$

periods was associated with risk for depression (corrected $p$-value $=0.01$, Table 1). There was no

288 evidence for associations between gene sets involved in the expression or closing of sensitive

289 periods and depression risk.

290 2) Are sensitive period genes implicated in depression risk developmentally regulated?

291 Developmental stage was significantly associated with expression levels in six opening

292 genes, explaining up to 54\% of the additional variation in gene-level expression beyond genetic

293 ancestry (Table S1). We observed preliminary evidence for developmental regulation in the

294 mPFC but not hippocampus or amygdala (Figure 3). Three of the six opening genes with

295 evidence of developmental regulation had a nadir of expression between ages 1 and 5: gene

296 expression levels between ages 1 and 5 years were statistically significantly different from other 
medRxiv preprint doi: https://doi.org/10.1101/2021.05.13.21257179; this version posted May 17, 2021. The copyright holder for this preprint (which was not certified by peer review) is the author/funder, who has granted medRxiv a license to display the preprint in perpetuity.

It is made available under a CC-BY-NC-ND 4.0 International license .

297 time points at GABRA1 ( $\beta=-2.33,95 \%$ C.I. $\left.[-3.47,-1.19], \mathrm{p}=3 \times 10^{-4}\right), G A D 1(\beta=-1.88,95 \%$ C.I.

$\left.298[-2.78,-0.98], \mathrm{p}=2 \times 10^{-4}\right)$, and GAD2 $\left(\beta=-2.32,95 \%\right.$ C.I. $\left.[-3.25,-1.39], \mathrm{p}=2 \times 10^{-5}\right)$.

299 We further examined whether genotype was associated with developmental expression of

300 these genes. To identify SNPs associated with developmental gene expression (which we term

301 “developmental expression quantitative trait loci”, or d-QTLs), we tested SNP-by-age

302 interactions on expression levels of the opening genes. Analyses were limited to the mPFC and

303 examined 144 independent SNPs (Supplemental Materials).

304 We found nominal evidence $(p<0.05)$ for SNP-by-age interactions at five loci (Table S2),

305 with two SNPs (rs 1442060, an intron variant in GABRA2; rs7900976, an intron variant in GAD2)

306 showing significant association after accounting for the number of SNPs tested within each gene.

307 As shown in Figure S1, these results revealed that GABRA2 was upregulated early in life and

308 downregulated later in life for both major and minor allele homozygotes, whereas the expression

309 level was more stable over time for heterozygotes. GAD2 was upregulated over time for major

310 allele homozygotes and downregulated for heterozygous individuals. There were only two data

311 points available from homozygous minor individuals, so the trend over time was not discernible.

312 These findings suggest that genetic variants may be associated with different patterns of gene

313 expressions over the life course.

314 3) How does variation in these sensitive period genes interact with the timing of exposure to

$315 \quad$ adversity to shape depressive symptoms?

316 Average depressive symptoms across adolescence were heritable in our sample

$317\left(\mathrm{~h}_{\mathrm{SNP}}^{2}=9.1 \%, \mathrm{SE}=0.05, p=0.03\right)$. The genome-wide PRS for depression was significantly

318 associated with average depressive symptoms $\left(\beta=0.40,95 \%\right.$ C.I. $\left.[0.31,0.49], \mathrm{p}<1 \times 10^{-22}\right)$. 
medRxiv preprint doi: https://doi.org/10.1101/2021.05.13.21257179; this version posted May 17, 2021. The copyright holder for this preprint (which was not certified by peer review) is the author/funder, who has granted medRxiv a license to display the preprint in perpetuity.

It is made available under a CC-BY-NC-ND 4.0 International license.

The gene set-level PRS representing all SNPs annotated to the opening genes did not

320 have a main effect on the outcome $(\beta=-0.01,95 \%$ C.I. $[-0.11,0.08], p=0.78)$. The environmental

321 exposure, socioeconomic disadvantage, showed a time-dependent association with depressive

322 symptoms. Specifically, the exposure between ages 1 and 5 years was associated with increased

323 symptoms $\left(\beta=0.79,95 \%\right.$ C.I. $\left.[0.5,1.08], \mathrm{p}=1.01 \times 10^{-7}\right)$. This effect estimate was almost twice as

324 large as the increase associated with exposure at other time points $(\beta=0.43,95 \%$ C.I. $[0.07,0.78]$,

$325 \mathrm{p}=0.02$ ). When assessing main genetic and environmental effects additively, we observed similar

326 patterns: both the genome-wide PRS and exposure to socioeconomic disadvantage were

327 associated with depressive symptoms, and no gene set-level PRS effect was detected (Table 2,

328 Models 4 and 5). There was no significant evidence supporting dGxE with either the genome-

329 wide PRS or the gene set-level PRS of the opening genes (Table 2, Models 6 and 7). These

330 findings suggest that there was little signal for gene-by-development interplay, though

331 environmental exposure and genetic risk may jointly shape depression risk additively.

\section{Discussion}

Three notable findings emerged from our analyses. First, we found that variations in

334 genes governing the onset of sensitive periods were associated with risk for depression at the

335 population level. The mechanism underlying this association remains to be determined.

336 However, we posit that because these genes are known to regulate the initial maturation of

337 inhibitory signaling during early development [6,12], their altered function might therefore delay

338 the onset of sensitive period plasticity. Such mistiming could result in aberrant responses to

339 external stimuli during the process of fear learning and other cognitive functions critical to

340 affective development [78] and thus increase risk for depression and other neuropsychiatric

341 disorders. By contrast, we found no effect on depression of genetic pathways involved in the 
medRxiv preprint doi: https://doi.org/10.1101/2021.05.13.21257179; this version posted May 17, 2021. The copyright holder for this preprint (which was not certified by peer review) is the author/funder, who has granted medRxiv a license to display the preprint in perpetuity.

It is made available under a CC-BY-NC-ND 4.0 International license .

342 duration or closure of sensitive periods. The lack of association with closing genes is somewhat

343 surprising given previous studies suggesting that PNN maturation plays an instrumental role in

344 the emergence of higher order functioning (e.g., social memory formation) [79], and has

345 protective effects against toxic stress exposures [42]. The lack of evidence from our study could

346 be due to the heterogeneity among genes included in the closing set. Among the 39 genes in this

347 set, some relate to the formation of PNNs (e.g., ACAN, RTN4R), while others affect myelin and

348 myelin-associated inhibitors that restrict plasticity (e.g., PIRB) [12]. Although these 39 genes all

349 regulate the closure of sensitive periods, they appeared to have mixed effects on depression risk:

350 namely, only 11 out of the 39 genes showed a gene-level association with depression risk. We

351 analyzed the entire closing set to preserve the biological interpretation of this pathway and avoid

352 cherry-picking, however, testing somewhat heterogeneous genes as one pathway might have

353 diluted the signals. Readers interested in seeing gene-level results are referred to Table S5.

354 Second, we showed that genes involved in sensitive period functioning were

355 developmentally regulated in the mPFC, though not hippocampus or amygdala. Configurations

356 of the prefrontal cortical network during sensitive periods have been implicated in different

357 developmental trajectories and vulnerability to neuropsychiatric disorders, suggesting that

358 plasticity of mPFC may play a prominent role in development [21]. The absence of evidence for

359 developmental regulation in amygdala or hippocampus was unexpected, because the trajectories

360 of GABAergic signaling markers were found to be nonlinear over time in these brain regions

361 within animal models [80]. Our inability to identify time-varying patterns in these regions could

362 be attributed to the limited sample size: although not reaching statistical significance, some genes

363 (e.g., GABRA1, GAD1, and GAD2) did show similar trends of expression in amygdala and

364 hippocampus. Moreover, the nadir in expression levels of opening genes between ages 1 and 5 
medRxiv preprint doi: https://doi.org/10.1101/2021.05.13.21257179; this version posted May 17, 2021. The copyright holder for this preprint (which was not certified by peer review) is the author/funder, who has granted medRxiv a license to display the preprint in perpetuity.

It is made available under a CC-BY-NC-ND 4.0 International license .

365 years suggests that this time period may be developmentally relevant. This decline in plasticity-

366 related transcriptional activities co-occurred with reported periods of decreased synaptogenesis

367 and increased pruning or maturation of the central nervous system, which may signal the start of

368 developing higher-order cognition or more complex behavior [81,82]. However, we were unable

369 to fully disentangle different patterns between individuals across time due to the lack of repeated

370 gene expression measures. Replication studies are needed to further confirm the importance of

371 the developmental window between ages 1 and 5 years. We also provided a proof of concept for

372 identifying genetic loci predicting developmental regulation of genes - which we labeled as d-

373 QTLs. Although our results are preliminary and suggestive given the restrictions of sample size

374 and data availability, the d-QTL framework holds potential for studying the heterogeneity of

375 sensitive period timing and responsivity across individuals with different genetic profiles.

376 Third, in a population-based sample of adolescents, we did not observe any evidence for

377 genetic main effects or gene-by-developmental timing of adversity interplay. However, we did

378 identify a sensitive period effect of exposure to socioeconomic disadvantage, between ages 1 and

3795 , which is consistent with prior research [72,83]. The lack of genetic associations with sensitive

380 period genes might reflect insufficient power in our study. As environmental perturbations likely

381 increase phenotypic heterogeneities and yield more nuanced effects, detecting gene-by-

382 environment interactions requires larger sample sizes [40,84]. Our sample size was smaller

383 compared to population-based cross-sectional analyses where effect modification of depression

384 PRS by environmental exposures have been observed [85]. Additionally, our data came from a

385 homogeneous sample of European ancestry children in the UK, where most families of

386 participants were relatively socioeconomically advantaged [64]. Thus, we might have been 
medRxiv preprint doi: https://doi.org/10.1101/2021.05.13.21257179; this version posted May 17, 2021. The copyright holder for this preprint (which was not certified by peer review) is the author/funder, who has granted medRxiv a license to display the preprint in perpetuity.

It is made available under a CC-BY-NC-ND 4.0 International license .

unable to capture large detrimental effects of extreme hardship and their potential interactions

388 with genetic variations.

Several limitations of our study are noted. First, the lack of detailed phenotypic data in

390 BrainSpan made it impossible for us to test whether developmental regulations of genetic

391 pathways were impacted by life experiences, and whether different trajectories may contribute to

392 risk for depression. By studying associations between phenotypic experiences and gene

393 expression levels across time in human, future studies can better link observable environmental

394 risks to underlying molecular changes. Second, all three data sources were comprised of

395 predominantly White populations, restricting the generalizability of our findings. It should

396 remain a priority of neuropsychiatric genetic studies to expand the recruitment and research of

397 non-White samples [86]. Third, as mentioned above, our analyses were limited by sample sizes

398 and characteristics of the samples. To fully address these issues, larger individual studies or

399 meta/mega-analyses including high risk samples and rigorous assessments of phenotypes are

400 warranted in future work.

401 In conclusion, our study provides a translational model for testing novel neurobiological

402 pathways by triangulating concepts and data from genetics, developmental sciences, and

403 epidemiology. Through the integration of genetic risk, experiences over the life course, and

404 physiological markers across domains of functioning, interdisciplinary translational studies hold

405 great potential to unravel the complexity of depression etiology and identify novel targets for

406 prevention or intervention. 
medRxiv preprint doi: https://doi.org/10.1101/2021.05.13.21257179; this version posted May 17, 2021. The copyright holder for this preprint (which was not certified by peer review) is the author/funder, who has granted medRxiv a license to display the preprint in perpetuity. It is made available under a CC-BY-NC-ND 4.0 International license .

Funding and Disclosure: Research reported in this publication was supported by the National Institute of Mental Health of the National Institutes of Health under Award Numbers K01MH102403 and R01MH113930 (Dr. Dunn) and K24MH094614 (Dr. Smoller). It was also supported in part by a NARSAD Young Investigator Grant from the Brain \& Behavior Research Foundation (Dr. Dunn) and an award from the Jacobs Foundation (Drs. Dunn and Takesian). The Psychiatric Genomics Consortium (PGC) has received major funding from the US National Institute of Mental Health and the US National Institute of Drug Abuse (U01 MH109528 and U01 MH1095320). The content is solely the responsibility of the authors and does not necessarily represent the official views of the National Institutes of Health.

The UK Medical Research Council and Wellcome (Grant ref: 217065/Z/19/Z) and the University of Bristol provide core support for ALSPAC. A comprehensive list of grants funding is available on the ALSPAC website (http://www.bristol.ac.uk/alspac/external/documents/grantacknowledgements.pdf). GWAS data was generated by Sample Logistics and Genotyping Facilities at Wellcome Sanger Institute and LabCorp (Laboratory Corporation of America) using support from 23 andMe, Inc. This publication is the work of the authors and all authors will serve as guarantors for the contents of this paper.

Dr. Smoller is an unpaid member of the Bipolar/Depression Research Community Advisory Panel of 23andMe, Inc., a member of the Leon Levy Foundation Neuroscience Advisory Board and received an honorarium for an internal seminar at Biogen, Inc. He is Principal Investigator of a collaborative study of the genetics of depression and bipolar disorder sponsored by $23 \mathrm{andMe}$, Inc., for which 23 andMe, Inc. provides analysis time as in-kind support but no payments. The remaining authors (including the contributing Consortium members) have nothing to disclose.

Acknowledgments: The authors thank Oliver Hoffman, $\mathrm{PhD}$, formerly of the Harvard Chan Bioinformatics Core, Harvard T.H. Chan School of Public Health, Boston, MA, Meeta Mistry, Virginia Fisher, and Kuang Zheng for their assistance with early data analyses. We are extremely grateful to all the families who took part in this study, the midwives for their help in recruiting them, and the whole ALSPAC team, which includes interviewers, computer and laboratory technicians, clerical workers, research scientists, volunteers, managers, receptionists and nurses. We would also like to thank the research participants and employees of $23 \mathrm{andMe}$, Inc. for making this work possible.

Author contributions: YZ, JWS, TKH, and ECD conceived and designed the analysis. ECD and contributing authors of the Major Depressive Disorder Working Group of the Psychiatric Genomics Consortium acquired the data. YZ, MJW, KMC, JCRT, and KAD performed the analysis. AAL, CL, AET, TKH, JWS, and ECD provided critical feedback on preliminary results and revised the analysis. YZ, MJW, KMC, and ECD drafted the manuscript. All authors critically reviewed the manuscript, gave their final approval, and agreed to be accountable for all aspects of the work in ensuring that questions related to the accuracy or integrity of any part of the work were appropriately investigated and resolved. 
medRxiv preprint doi: https://doi.org/10.1101/2021.05.13.21257179; this version posted May 17, 2021. The copyright holder for this preprint (which was not certified by peer review) is the author/funder, who has granted medRxiv a license to display the preprint in perpetuity.

4501 Bornstein MH. Sensitive periods in development: Structural characteristics and causal interpretations. Psychological Bulletin. 1989;105(2):179-97. Bailey DB, Bruer JT, Symons FJ, Lichtman JW. Critical Thinking about Critical Periods. A Series from the National Center for Early Development and Learning. 2001.

4 Dunn EC, McLaughlin KA, Slopen N, Rosand J, Smoller JW. Developmental timing of child maltreatment and symptoms of depression and suicidal ideation in young adulthood: Results from the National Longitudinal Study on Adolescent Health. Depress Anxiety. 2013;30(10).

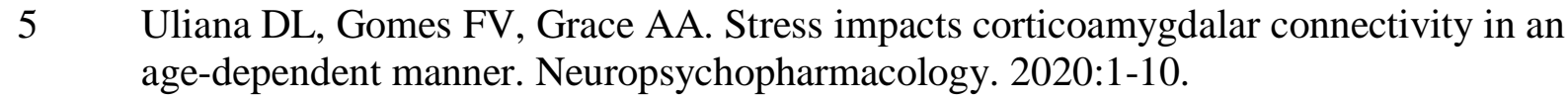

6 Hensch TK. Critical Period Regulation. Annual Review of Neuroscience. 2004;27(1):549-79.

7 Hooks BM, Chen C. Critical periods in the visual system: changing views for a model of experience-dependent plasticity. Neuron. 2007;56(2):312-26. Yang E-J, Lin EW, Hensch TK. Critical period for acoustic preference in mice. Proc Natl 8 Yang E-J, Lin EW, Hensch TK. Critical period

9 Sharma A, Campbell J, Cardon G. Developmental and cross-modal plasticity in deafness: Evidence from the P1 and N1 event related potentials in cochlear implanted children. Int J Psychophysiol. 2015;95(2):135-44.

10 Hakuta K, Bialystok E, Wiley E. Critical Evidence: A Test of the Critical-Period Hypothesis for Second-Language Acquisition. Psychological Science. 2016.

11 Fox SE, Levitt P, Nelson CA. How the Timing and Quality of Early Experiences Influence the Development of Brain Architecture. Child Dev. 2010;81(1):28-40.

12 Takesian AE, Hensch TK. Balancing Plasticity/Stability Across Brain Development. Progress in Brain Research. 2013. p. 3-34.

13 Hensch TK. Critical period plasticity in local cortical circuits. Nature Reviews Neuroscience. 2005;6(11):877-88.

14 Kaneko M, Stellwagen D, Malenka RC, Stryker MP. Tumor Necrosis Factor- $\alpha$ mediates one component of competitive, experience-dependent plasticity in developing visual cortex. Neuron. 2008;58(5):673-80.

15 Tropea D, Van Wart A, Sur M. Molecular mechanisms of experience-dependent plasticity in visual cortex. Philos Trans R Soc Lond B Biol Sci. 2009;364(1515):341-55.

16 Huang ZJ, Kirkwood A, Pizzorusso T, Porciatti V, Morales B, Bear MF, et al. BDNF Regulates the Maturation of Inhibition and the Critical Period of Plasticity in Mouse Visual Cortex. Cell. 1999;98(6):739-55.

17 Anomal R, Villers-Sidani dE, Merzenich MM, Panizzutti R. Manipulation of BDNF Signaling Modifies the Experience-Dependent Plasticity Induced by Pure Tone Exposure during the Critical Period in the Primary Auditory Cortex. PLOS ONE. 2013;8(5):e64208. Lee HHC, Bernard C, Ye Z, Acampora D, Simeone A, Prochiantz A, et al. Genetic Otx2 
medRxiv preprint doi: https://doi.org/10.1101/2021.05.13.21257179; this version posted May 17, 2021. The copyright holder for this preprint (which was not certified by peer review) is the author/funder, who has granted medRxiv a license to display the preprint in perpetuity. It is made available under a CC-BY-NC-ND 4.0 International license .

19 Fagiolini M, Katagiri H, Miyamoto H, Mori H, Grant SGN, Mishina M, et al. Separable features of visual cortical plasticity revealed by $\mathrm{N}$-methyl-d-aspartate receptor $2 \mathrm{~A}$ signaling. PNAS. 2003;100(5):2854-59.

20 Nagakura I, Wart AV, Petravicz J, Tropea D, Sur M. STAT1 Regulates the Homeostatic Component of Visual Cortical Plasticity via an AMPA Receptor-Mediated Mechanism. J Neurosci. 2014;34(31):10256-63.

21 Guirado R, Perez-Rando M, Ferragud A, Gutierrez-Castellanos N, Umemori J, Carceller $\mathrm{H}$, et al. A Critical Period for Prefrontal Network Configurations Underlying Psychiatric Disorders and Addiction. Front Behav Neurosci. 2020;14.

22 Yu H, Yan H, Li J, Li Z, Zhang X, Ma Y, et al. Common variants on 2p16.1, 6p22.1 and 10q24.32 are associated with schizophrenia in Han Chinese population. Molecular Psychiatry. 2017;22(7):954-60.

23 Nagel M, Jansen PR, Stringer S, Watanabe K, Leeuw dCA, Bryois J, et al. Meta-analysis of genome-wide association studies for neuroticism in 449,484 individuals identifies novel genetic loci and pathways. Nature Genetics. 2018;50(7):920-27.

24 Hall LS, Adams MJ, Arnau-Soler A, Clarke T-K, Howard DM, Zeng Y, et al. Genomewide meta-analyses of stratified depression in Generation Scotland and UK Biobank. Translational Psychiatry. 2018;8.

25 Grove J, Ripke S, Als TD, Mattheisen M, Walters RK, Won H, et al. Identification of common genetic risk variants for autism spectrum disorder. Nature Genetics. 2019;51(3):431-44.

$26 \mathrm{Li}$ Z, Chen J, Yu H, He L, Xu Y, Zhang D, et al. Genome-wide association analysis identifies 30 new susceptibility loci for schizophrenia. Nature Genetics. 2017;49(11):1576-83.

27 Lam M, Hill WD, Trampush JW, Yu J, Knowles E, Davies G, et al. Pleiotropic MetaAnalysis of Cognition, Education, and Schizophrenia Differentiates Roles of Early Neurodevelopmental and Adult Synaptic Pathways. The American Journal of Human Genetics. 2019;105(2):334-50.

28 Periyasamy S, John S, Padmavati R, Rajendren P, Thirunavukkarasu P, Gratten J, et al. Association of Schizophrenia Risk With Disordered Niacin Metabolism in an Indian Genome-wide Association Study. JAMA Psychiatry. 2019;76(10):1026-34.

29 Ikeda M, Takahashi A, Kamatani Y, Momozawa Y, Saito T, Kondo K, et al. GenomeWide Association Study Detected Novel Susceptibility Genes for Schizophrenia and Shared Trans-Populations/Diseases Genetic Effect. Schizophr Bull. 2019;45(4):824-34.

30 Stahl EA, Breen G, Forstner AJ, McQuillin A, Ripke S, Trubetskoy V, et al. Genomewide association study identifies 30 loci associated with bipolar disorder. Nature Genetics. 2019;51(5):793-803.

31 Baselmans BML, Jansen R, Ip HF, Dongen vJ, Abdellaoui A, Weijer vdMP, et al. Multivariate genome-wide analyses of the well-being spectrum. Nature Genetics. 2019;51(3):445-51.

32 Johnson FK, Delpech J-C, Thompson GJ, Wei L, Hao J, Herman P, et al. Amygdala hyper-connectivity in a mouse model of unpredictable early life stress. Translational Psychiatry. 2018;8(1):1-14.

33 Peña CJ, Smith M, Ramakrishnan A, Cates HM, Bagot RC, Kronman HG, et al. Early life stress alters transcriptomic patterning across reward circuitry in male and female mice. Nature Communications. 2019;10(1):5098. 
medRxiv preprint doi: https://doi.org/10.1101/2021.05.13.21257179; this version posted May 17, 2021. The copyright holder for this preprint (which was not certified by peer review) is the author/funder, who has granted medRxiv a license to display the preprint in perpetuity. It is made available under a CC-BY-NC-ND 4.0 International license .

34 Andersen SL, Tomada A, Vincow ES, Valente E, Polcari A, Teicher MH. Preliminary Evidence for Sensitive Periods in the Effect of Childhood Sexual Abuse on Regional Brain Development. JNP. 2008;20(3):292-301.

35 Bos K, Zeanah CH, Fox NA, Drury SS, McLaughlin KA, Nelson CA. Psychiatric Outcomes in Young Children with a History of Institutionalization. Harv Rev Psychiatry. 2011;19(1):15-24.

36 Dunn EC, Nishimi K, Powers A, Bradley B. Is developmental timing of trauma exposure associated with depressive and post-traumatic stress disorder symptoms in adulthood? J Psychiatr Res. 2017;84:119-27.

37 Greenough WT, Black JE, Wallace CS. Experience and brain development. Child Dev. 1987;58(3):539-59.

38 Gilbert R, Widom CS, Browne K, Fergusson D, Webb E, Janson S. Burden and consequences of child maltreatment in high-income countries. Lancet. 2009;373(9657):68-81.

39 McLaughlin KA, Sheridan MA, Nelson CA. Neglect as a Violation of Species-Expectant Experience: Neurodevelopmental Consequences. Biological Psychiatry. 2017;82(7):46271.

40 Dunn EC, Brown RC, Dai Y, Rosand J, Nugent NR, Amstadter AB, et al. Genetic determinants of depression: Recent findings and future directions. Harv Rev Psychiatry. 2015;23(1):1-18.

41 Uher R, Zwicker A. Etiology in psychiatry: embracing the reality of poly-geneenvironmental causation of mental illness. World Psychiatry. 2017;16(2):121-29.

42 Do KQ, Cuenod M, Hensch TK. Targeting Oxidative Stress and Aberrant Critical Period Plasticity in the Developmental Trajectory to Schizophrenia. Schizophr Bull. 2015;41(4):835-46.

43 Black CN, Bot M, Scheffer PG, Cuijpers P, Penninx BWJH. Is depression associated with increased oxidative stress? A systematic review and meta-analysis.

44 Liu T, Zhong S, Liao X, Chen J, He T, Lai S, et al. A Meta-Analysis of Oxidative Stress Markers in Depression. PLOS ONE. 2015;10(10):e0138904.

45 Theall KP, Drury SS, Shirtcliff EA. Cumulative Neighborhood Risk of Psychosocial Stress and Allostatic Load in Adolescents. Am J Epidemiol. 2012;176(suppl_7):S164S74.

46 Drury SS, Theall K, Gleason MM, Smyke AT, De Vivo I, Wong JYY, et al. Telomere length and early severe social deprivation: linking early adversity and cellular aging. Molecular Psychiatry. 2012;17(7):719-27.

47 Luscher B, Shen Q, Sahir N. The GABAergic deficit hypothesis of major depressive disorder. Molecular Psychiatry. 2011;16(4):383-406.

48 Cameron JL, Eagleson KL, Fox NA, Hensch TK, Levitt P. Social Origins of Developmental Risk for Mental and Physical Illness. J Neurosci. 2017;37(45):10783-91. LeMoult J, Humphreys KL, Tracy A, Hoffmeister J-A, Ip E, Gotlib IH. Meta-analysis: Exposure to Early Life Stress and Risk for Depression in Childhood and Adolescence. Journal of the American Academy of Child \& Adolescent Psychiatry. 2020;59(7):842-55. importance of basic animal research for neuropsychiatric disorders. Neuropsychopharmacology. 2019;44(8):1349-53. 
medRxiv preprint doi: https://doi.org/10.1101/2021.05.13.21257179; this version posted May 17, 2021. The copyright holder for this preprint (which was not certified by peer review) is the author/funder, who has granted medRxiv a license to display the preprint in perpetuity. It is made available under a CC-BY-NC-ND 4.0 International license .

51 The Schizophrenia Working Group of the Psychiatric Genomics C, Rammos A, Gonzalez LAN, Weinberger DR, Mitchell KJ, Nicodemus KK. The role of polygenic risk score gene-set analysis in the context of the omnigenic model of schizophrenia. Neuropsychopharmacology. 2019;44(9):1562-69.

52 Mota NR, Poelmans G, Klein M, Torrico B, Fernàndez-Castillo N, Cormand B, et al. Cross-disorder genetic analyses implicate dopaminergic signaling as a biological link between Attention-Deficit/Hyperactivity Disorder and obesity measures.

Neuropsychopharmacology. 2020;45(7):1188-95.

53 Howard DM, Adams MJ, Clarke TK, Hafferty JD, Gibson J, Shirali M, et al. Genomewide meta-analysis of depression identifies 102 independent variants and highlights the importance of the prefrontal brain regions. Nat Neurosci. 2019.

54 de Leeuw CA, Mooij JM, Heskes T, Posthuma D. MAGMA: Generalized Gene-Set Analysis of GWAS Data. PLoS computational biology. 2015;11(4).

55 Wang K, Li M, Hakonarson H. Analysing biological pathways in genome-wide association studies. Nature Reviews Genetics. 2010;11(12):843-54.

56 Glanville KP, Coleman JRI, Hanscombe KB, Euesden J, Choi SW, Purves KL, et al. Classical Human Leukocyte Antigen Alleles and C4 Haplotypes Are Not Significantly Associated With Depression. Biological Psychiatry. 2020;87(5):419-30.

57 Heim C, Binder EB. Current research trends in early life stress and depression: Review of human studies on sensitive periods, gene-environment interactions, and epigenetics. Experimental Neurology. 2012;233(1):102-11.

58 Kang HJ, Kawasawa YI, Cheng F, Zhu Y, Xu X, Li M, et al. Spatio-temporal transcriptome of the human brain. Nature. 2011;478(7370):483-89.

59 Gulsuner S, Walsh T, Watts AC, Lee MK, Thornton AM, Casadei S, et al. Spatial and Temporal Mapping of De novo Mutations in Schizophrenia To a Fetal Prefrontal Cortical Network. Cell. 2013;154(3):518-29.

60 Bolstad BM, Irizarry RA, Astrand M, Speed TP. A comparison of normalization methods for high density oligonucleotide array data based on variance and bias. Bioinformatics. 2003;19(2):185-93.

61 Das D, Clark TA, Schweitzer A, Yamamoto M, Marr H, Arribere J, et al. A correlation with exon expression approach to identify cis-regulatory elements for tissue-specific alternative splicing. Nucleic Acids Research. 2007;35(14):4845-57.

62 Laiho A, Elo LL. A Note on an Exon-Based Strategy to Identify Differentially Expressed Genes in RNA-Seq Experiments. PLOS ONE. 2014;9(12):e115964.

63 Boyd A, Golding J, Macleod J, Lawlor DA, Fraser A, Henderson J, et al. Cohort Profile: The 'Children of the 90s' - the index offspring of the Avon Longitudinal Study of Parents and Children. International Journal of Epidemiology. 2013;42(1):111-27.

64 Fraser A, Macdonald-Wallis C, Tilling K, Boyd A, Golding J, Davey Smith G, et al. Cohort Profile: The Avon Longitudinal Study of Parents and Children: ALSPAC mothers cohort. International Journal of Epidemiology. 2013;42(1):97-110.

65 Northstone K, Lewcock M, Groom A, Boyd A, Macleod J, Timpson N, et al. The Avon Longitudinal Study of Parents and Children (ALSPAC): an update on the enrolled sample of index children in 2019. Wellcome Open Res. 2019;4:51.(2004).

67 Harris PA, Taylor R, Thielke R, Payne J, Gonzalez N, Conde JG. Research electronic data capture (REDCap) — A metadata-driven methodology and workflow process for 
medRxiv preprint doi: https://doi.org/10.1101/2021.05.13.21257179; this version posted May 17, 2021. The copyright holder for this preprint (which was not certified by peer review) is the author/funder, who has granted medRxiv a license to display the preprint in perpetuity. It is made available under a CC-BY-NC-ND 4.0 International license .

providing translational research informatics support. Journal of Biomedical Informatics. 2009;42(2):377-81.

68 Harris PA, Taylor R, Minor BL, Elliott V, Fernandez M, O'Neal L, et al. The REDCap consortium: Building an international community of software platform partners. Journal of Biomedical Informatics. 2019;95:103208.

69 Messer SC, Angold A, Costello J, Loeber R, Van Kammen W, Stouthamer-Loeber M. Development of a Short Questionnaire for use in Epidemiological Studies of Depression in Children and Adolescents: Factor Composition and Structure Across Development. International Journal of Methods in Psychiatric Research. 1995;5:251-62.

70 Slopen N, Koenen KC, Kubzansky LD. Childhood adversity and immune and inflammatory biomarkers associated with cardiovascular risk in youth: a systematic review. Brain, behavior, and immunity. 2012;26(2):239-50.

71 Slopen N, Koenen KC, Kubzansky LD. Cumulative Adversity in Childhood and Emergent Risk Factors for Long-Term Health. The Journal of Pediatrics. 2014;164(3):631-38.e2.

72 Dunn EC, Soare TW, Raffeld MR, Busso DS, Crawford KM, Davis KA, et al. What life course theoretical models best explain the relationship between exposure to childhood adversity and psychopathology symptoms: recency, accumulation, or sensitive periods? Psychological medicine. 2018:1-11.

73 McLaughlin KA, Breslau J, Green JG, Lakoma MD, Sampson NA, Zaslavsky AM, et al. Childhood socio-economic status and the onset, persistence, and severity of DSM-IV mental disorders in a US national sample. Social Science \& Medicine. 2011;73(7):108896.

74 Boe T, Balaj M, Eikemo TA, McNamara CL, Solheim EF. Financial difficulties in childhood and adult depression in Europe. European journal of public health. 2017;27(suppl_1):96-101.

75 Teicher MH, Anderson CM, Polcari A. Childhood maltreatment is associated with reduced volume in the hippocampal subfields CA3, dentate gyrus, and subiculum. PNAS. 2012;109(9):E563-E72.

76 Purcell S, Neale B, Todd-Brown K, Thomas L, Ferreira Manuel AR, Bender D, et al. PLINK: A Tool Set for Whole-Genome Association and Population-Based Linkage Analyses. American Journal of Human Genetics. 2007;81(3):559-75.

77 van Buuren S, Groothuis-Oudshoorn K. mice: Multivariate Imputation by Chained Equations in R. Journal of Statistical Software. 2011;45:urn:issn:1548-7660.

78 Hartley CA, Lee FS. Sensitive Periods in Affective Development: Nonlinear Maturation of Fear Learning. Neuropsychopharmacology. 2015;40(1):50-60.

79 Domínguez S, Rey CC, Therreau L, Fanton A, Massotte D, Verret L, et al. Maturation of PNN and ErbB4 Signaling in Area CA2 during Adolescence Underlies the Emergence of PV Interneuron Plasticity and Social Memory. Cell Reports. 2019;29(5):1099-112.e4.

80 King EC, Pattwell SS, Sun A, Glatt CE, Lee FS. Nonlinear developmental trajectory of fear learning and memory. Annals of the New York Academy of Sciences. 2013;1304(1):62-69.

81 Huttenlocher PR, de Courten C, Garey LJ, Van der Loos H. Synaptogenesis in human visual cortex - evidence for synapse elimination during normal development. Neuroscience Letters. 1982;33(3):247-52. 
medRxiv preprint doi: https://doi.org/10.1101/2021.05.13.21257179; this version posted May 17, 2021. The copyright holder for this preprint

(which was not certified by peer review) is the author/funder, who has granted medRxiv a license to display the preprint in perpetuity.

It is made available under a CC-BY-NC-ND 4.0 International license .

67582 Silbereis John C, Pochareddy S, Zhu Y, Li M, Sestan N. The Cellular and Molecular

$676 \quad$ Landscapes of the Developing Human Central Nervous System. Neuron. 2016;89(2):248-

$677 \quad 68$.

67883 Gilman SE, Kawachi I, Fitzmaurice GM, Buka SL. Socioeconomic status in childhood

679 and the lifetime risk of major depression. International Journal of Epidemiology.

$680 \quad 2002 ; 31(2): 359-67$.

68184 Marigorta UM, Gibson G. A simulation study of gene-by-environment interactions in

$682 \quad$ GWAS implies ample hidden effects. Front Genet. 2014;5.

68385 Coleman JRI, Peyrot WJ, Purves KL, Davis KAS, Rayner C, Choi SW, et al. Genome-

684 wide gene-environment analyses of major depressive disorder and reported lifetime

685 traumatic experiences in UK Biobank. Molecular Psychiatry. 2020;25(7):1430-46.

68686 Wojcik GL, Graff M, Nishimura KK, Tao R, Haessler J, Gignoux CR, et al. Genetic

$687 \quad$ analyses of diverse populations improves discovery for complex traits. Nature.

$688 \quad 2019 ; 570(7762): 514-18$.

689 
medRxiv preprint doi: https://doi.org/10.1101/2021.05.13.21257179; this version posted May 17, 2021. The copyright holder for this preprint (which was not certified by peer review) is the author/funder, who has granted medRxiv a license to display the preprint in perpetuity.

It is made available under a CC-BY-NC-ND 4.0 International license .

Table 1. Gene set association analysis for genetic pathways regulating sensitive periods using data from a genome-wide meta-analysis of depression $(\mathrm{n}=807,553)$.

\begin{tabular}{lccccc}
\hline $\begin{array}{l}\text { Gene set } \\
\text { (sensitive period functioning) }\end{array}$ & Number of genes & Beta & SE & Unadjusted p-value & Corrected p-value \\
\hline opening & 15 & 0.84 & 0.31 & 0.0032 & $\mathbf{0 . 0 1}$ \\
closing & 39 & 0.27 & 0.18 & 0.0656 & 0.1806 \\
expression & 8 & 0.03 & 0.42 & 0.4743 & 0.8493 \\
\hline
\end{tabular}

These results came from the most recent genome-wide meta-analysis of depression [53]. Using the Multimarker Analysis of GenoMic Annotation (MAGMA) software, we first annotated SNPs to genes, ran a gene level analysis, and then ran a competitive gene-set analysis using the gene sets as described, testing the null hypothesis that genes in the tested gene-set were jointly no more associated with the phenotype than genes not in the gene set. The corrected p-value refers to $\mathrm{p}$-values based on 10,000 random permutations, which empirically accounted for multiple testing. 
Table 2. Effect estimates of main genetic effects, main environmental effect, and GxE interactions using data from ALSPAC (n=6,254).

\begin{tabular}{|c|c|c|c|c|}
\hline & $\begin{array}{l}\text { Effect } \\
\text { estimate }\end{array}$ & $\begin{array}{l}\text { Standard } \\
\text { error }\end{array}$ & p-value & $95 \% \mathrm{CI}$ \\
\hline \multicolumn{5}{|l|}{ Model 1: Main genetic effect, genome-wide PRS } \\
\hline Standardized PRS for depression $(\mathrm{p}<0.05)$ & 0.40 & 0.05 & $<1 \times 10^{-22}$ & $(0.31,0.49)$ \\
\hline \multicolumn{5}{|l|}{ Model 2: Main genetic effect, opening genes PRS } \\
\hline Standardized genetic score of opening genes & -0.01 & 0.05 & 0.78 & $(-0.11,0.08)$ \\
\hline \multicolumn{5}{|l|}{ Model 3: Main environmental effect } \\
\hline Exposure to socioeconomic disadvantage between 1 and 5 years & 0.79 & 0.15 & $1.07 \times 10^{-7}$ & $(0.5,1.08)$ \\
\hline Exposure at other time points & 0.43 & 0.18 & 0.02 & $(0.07,0.78)$ \\
\hline \multicolumn{5}{|l|}{ Model 4: Additive genetic and environmental effects, genome-wide PRS } \\
\hline Standardized PRS for depression $(\mathrm{p}<0.05)$ & 0.39 & 0.05 & $4.44 \times 10^{-16}$ & $(0.30,0.48)$ \\
\hline Exposure to socioeconomic disadvantage between 1 and 5 years & 0.75 & 0.15 & $4.72 \times 10^{-7}$ & $(0.46,1.04)$ \\
\hline Exposure at other time points & 0.40 & 0.18 & 0.03 & $(0.04,0.75)$ \\
\hline \multicolumn{5}{|l|}{ Model 5: Additive genetic and environmental effects, opening genes PRS } \\
\hline Standardized genetic score of opening genes & -0.01 & 0.05 & 0.75 & $(-0.11,0.08)$ \\
\hline Exposure to socioeconomic disadvantage between 1 and 5 years & 0.79 & 0.15 & $9.67 \times 10^{-8}$ & $(0.50,1.08)$ \\
\hline Exposure at other time points & 0.43 & 0.18 & 0.02 & $(0.08,0.78)$ \\
\hline \multicolumn{5}{|l|}{ Model 6: Gene and environment interaction, genome-wide PRS } \\
\hline Standardized PRS for depression $(\mathrm{p}<0.05)$ & 0.37 & 0.05 & $4.20 \times 10^{-12}$ & $(0.26,0.47)$ \\
\hline Exposure to socioeconomic disadvantage between 1 and 5 years & 0.72 & 0.15 & $1.15 \times 10^{-6}$ & $(0.43,1.01)$ \\
\hline Exposure at other time points & 0.40 & 0.18 & 0.03 & $(0.05,0.76)$ \\
\hline PRS for depression $\mathrm{x}$ exposure between 1 and 5 years & 0.26 & 0.15 & 0.09 & $(-0.03,0.55)$ \\
\hline PRS for depression $\mathrm{x}$ exposure at other time points & -0.08 & 0.18 & 0.66 & $(-0.43,0.27)$ \\
\hline \multicolumn{5}{|l|}{ Model 7: Gene and environment interaction, opening genes PRS } \\
\hline Standardized PRS of opening genes & -0.04 & 0.05 & 0.40 & $(-0.15,0.06)$ \\
\hline Exposure to socioeconomic disadvantage between 1 and 5 years & 0.79 & 0.15 & $1.09 \times 10^{-7}$ & $(0.50,1.08)$ \\
\hline Exposure at other time points & 0.44 & 0.18 & 0.02 & $(0.08,0.79)$ \\
\hline Opening genes PRS x exposure between 1 and 5 years & 0.14 & 0.15 & 0.35 & $(-0.16,0.44)$ \\
\hline Opening genes PRS $\mathrm{x}$ exposure at other time points & 0.18 & 0.17 & 0.31 & $(-0.16,0.52)$ \\
\hline
\end{tabular}


medRxiv preprint doi: https://doi.org/10.1101/2021.05.13.21257179; this version posted May 17, 2021. The copyright holder for this preprint (which was not certified by peer review) is the author/funder, who has granted medRxiv a license to display the preprint in perpetuity.

It is made available under a CC-BY-NC-ND 4.0 International license .

Figure 1. Gene sets regulating three aspects of sensitive period functioning in the sensory systems of mice.

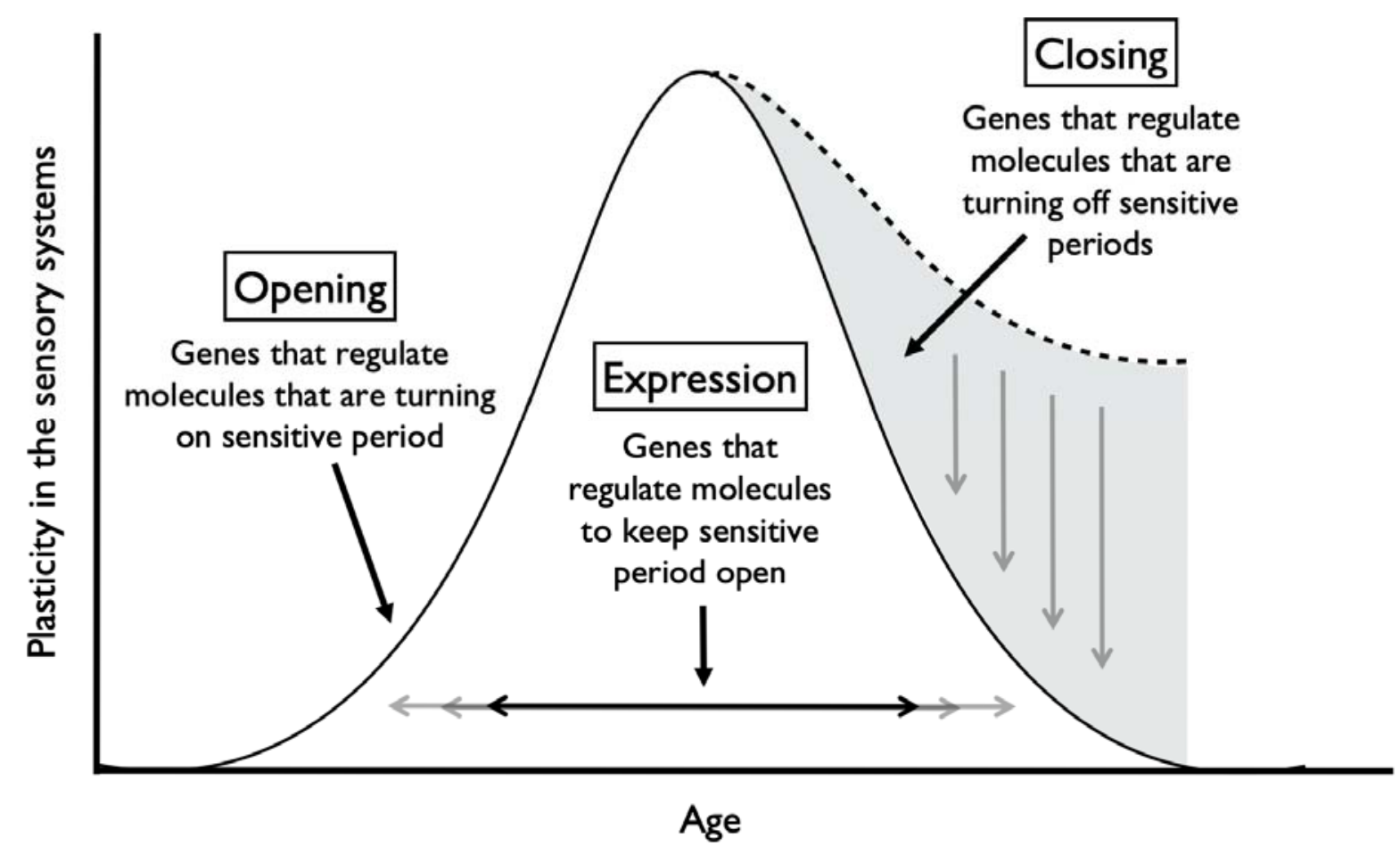

Note: Gene sets identified by Hensch (2005) and Takesian and Hensch (2013). Opening genes: BDNF, ARNTL, CLOCK, GABBR1, GABRA1, GABRA2, GABRB3, GAD1, GAD2, SLC6A1, NTRK2, OTX2, NPTX2, HTR3A, CHRNA4 Expression genes: CREB1, KCNK2, NGF, GRIN2A, DLG4, PVALB, STAT1, TNF Closing genes: OTX2, GCLC, GCLM, LYNX1, MAG, MBP, HLA-C, HLA-A, HLA-B, PODN, LILRB3, LILRB1, PTPRS, RTN4, ACAN, BCAN, HAPLN1, HAPLN3, HAPLN4, NCAN, PTS, TNR, VCAN, ADAMTS15, ADAMTS4, ADAMTS8, CSGALNACT1, HAS1, HAS2, HAS3, MME, MMP15, MMP24, MMP3, MMP8, DLG4, PILRB, CAM5, NCAM1 
medRxiv preprint doi: https://doi.org/10.1101/2021.05.13.21257179; this version posted May 17, 2021. The copyright holder for this preprint (which was not certified by peer review) is the author/funder, who has granted medRxiv a license to display the preprint in perpetuity.

It is made available under a CC-BY-NC-ND 4.0 International license .

Figure 2. Systematic approach to examining the role of sensitive period-regulating genes, alone and in interaction with exposure to adversity, on risk for depression.

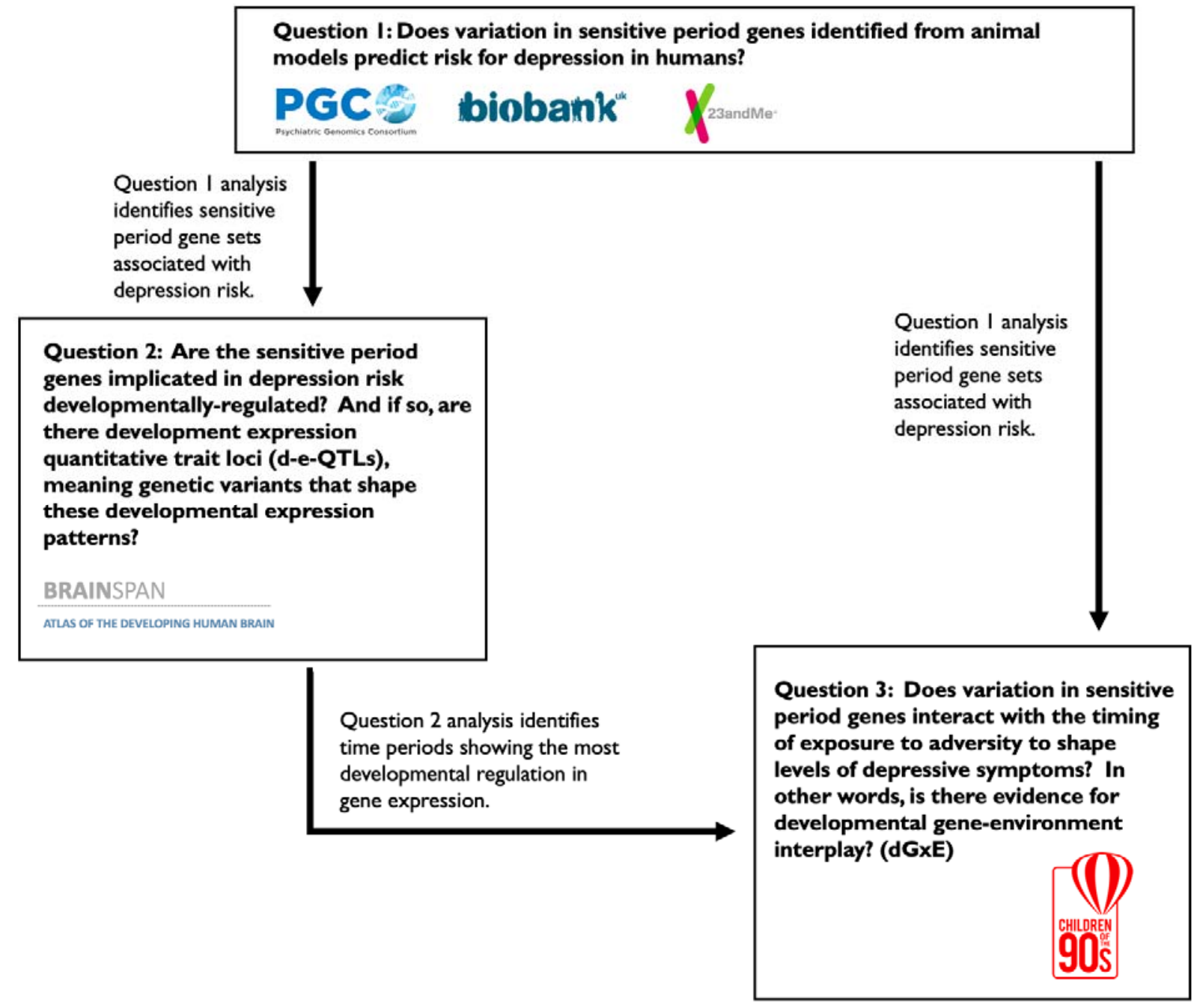

Note: We approached the above three questions systematically and sequentially, with results from each stage of analysis guiding our approach at the next stage. Specifically, gene sets associated with depression risk in question 1 analysis used to address question 2, where we characterized the developmental trajectories of their gene expression levels and examined whether the trajectories were shaped by certain variants. Similarly, variants annotated to genes in gene sets associated with depression risk were used to compute a gene-set genetic risk score in question 3. Results from question 2 analysis suggested the existence of a biologically-defined sensitive period based on levels of gene expression, which guided how the timing of environmental exposure was parameterized in question 3 analysis. 
medRxiv preprint doi: https://doi.org/10.1101/2021.05.13.21257179; this version posted May 17, 2021. The copyright holder for this preprint (which was not certified by peer review) is the author/funder, who has granted medRxiv a license to display the preprint in perpetuity.

It is made available under a CC-BY-NC-ND 4.0 International license .

Figure 3. Temporal expression patterns of genes involved in regulating the opening of sensitive periods.
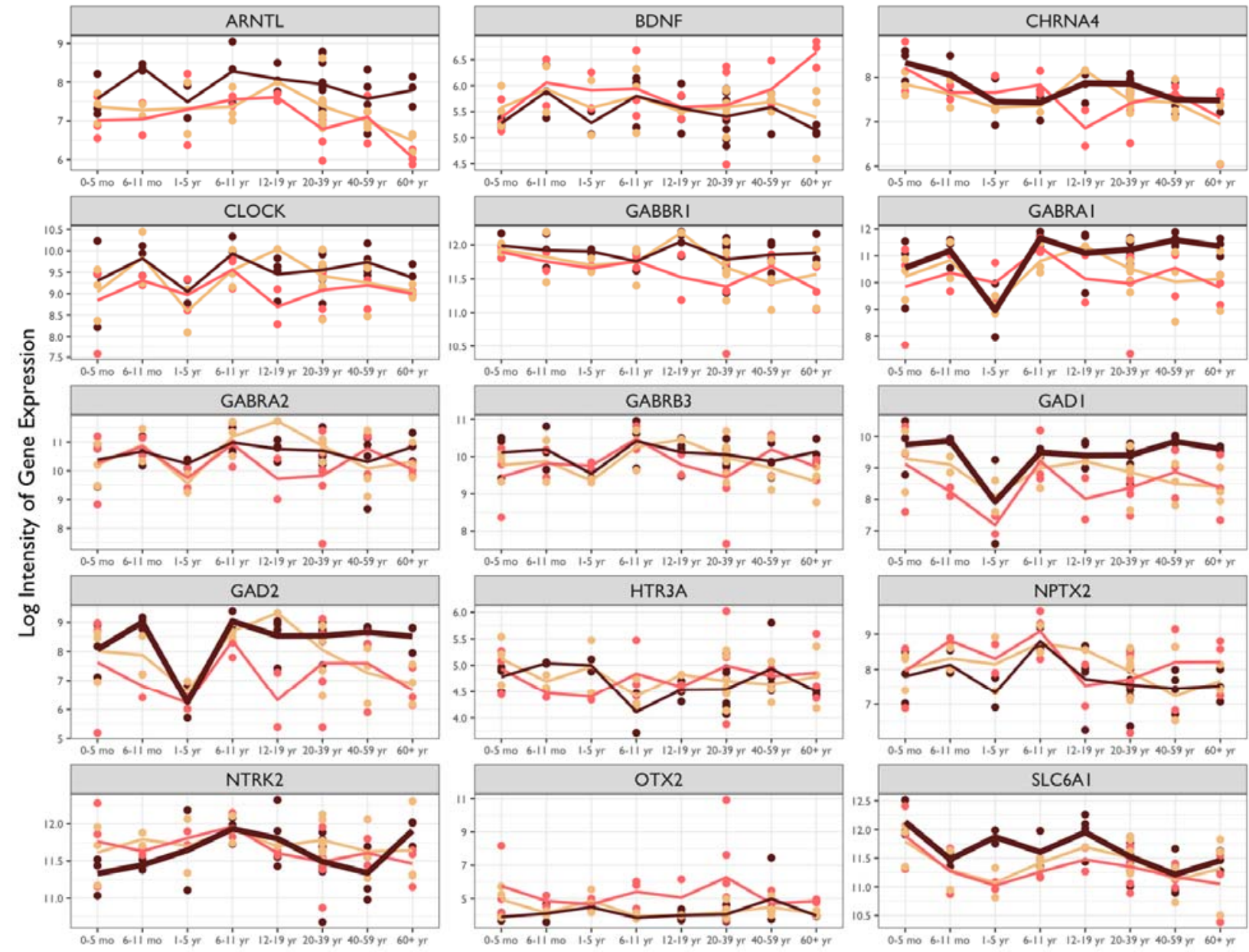

Developmentally regulated? - No - Yes Brain Region $\rightarrow$ AMY $\rightarrow$ HIP $\rightarrow$ mPFC

Note $:$ AMY = Amygdala; HIP = Hippocampus; $\mathrm{mPFC}=$ Medial Prefrontal Cortex.

Thicker lines indicated a significant association between developmental stage and gene expression (i.e., developmental regulation) based on results from multiple regression analyses. The evidence for developmental regulation was found in the mPFC. In particular, three genes showed decreased expression between ages 1 and 5 (GABRA1, GAD1, and GAD2). 